\title{
Predicting Video Game Addiction Through the Dimensions of Consumer Video Game Engagement: Quantitative and Cross-sectional Study
}

Amir Zaib Abbasi ${ }^{1,2^{*}}$, PhD; Umair Rehman ${ }^{3 *}, \mathrm{PhD} ;$ Zahra Afaq $^{4}$, MPhil; Mir Abdur Rafeh ${ }^{1}$, MPhil; Helmut Hlavacs ${ }^{5 *}$, $\mathrm{PhD}$; Mohammed A Mamun ${ }^{6,7}$, HSC; Muhammad Umair $\mathrm{Shah}^{8}, \mathrm{PhD}$

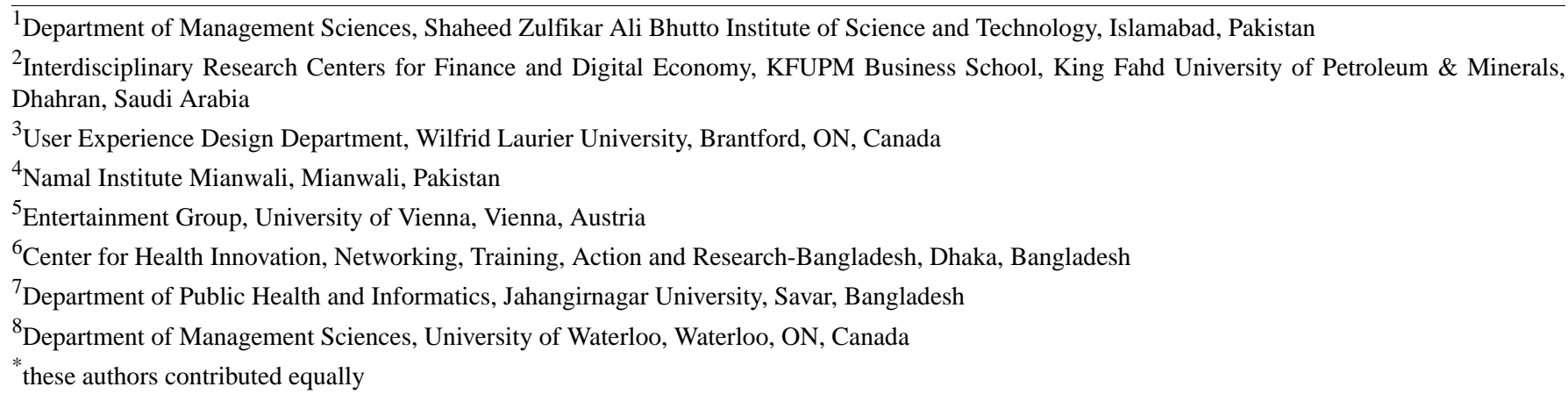

\section{Corresponding Author:}

Amir Zaib Abbasi, $\mathrm{PhD}$

Department of Management Sciences

Shaheed Zulfikar Ali Bhutto Institute of Science and Technology

Street \# 09, Plot \# 67 Sector H-8/4

Islamabad, 46000

Pakistan

Phone: 92514863363 ext 517

Email: aamir.zaib.abbasi@gmail.com

\section{Abstract}

Background: Video games are expanding exponentially with their increased popularity among users. However, this popularity has also led to an increase in reported video game addiction. There may be consumer engagement-related factors that may influence video game addiction.

Objective: This study aims to empirically examine the impact of the dimensions of consumer video game engagement on video game addiction. The dimensions are dedication, absorption, conscious attention, social connection, enthusiasm, and interaction. We utilize the uses and gratifications theory to study the video game engagement dimensions as potential factors through which gamers feel gratified and engaged in video game playing. Additionally, this study incorporates the cultivation theory to investigate how video game engagement factors trigger video game addiction.

Methods: A two-step process was applied for data analysis on valid cases of 176 gamers aged 15-25 years: video game addiction was specified and validated as a reflective-formative construct, and hypothesis testing was later performed using the WarpPLS on valid respondents.

Results: The analysis uncovered 2 dimensions of video game engagement: social connection with $P=.08$ and interaction with $P=.49$, which did not significantly contribute to video game addiction.

Conclusions: This study offers unique insights to a myriad of stakeholders, mostly psychologists and psychiatrists, who routinely prescribe behavior modification techniques to treat video game addiction.

(JMIR Serious Games 2021;9(4):e30310) doi: 10.2196/30310

\section{KEYWORDS}

consumer video game engagement; dedication; absorption; social connection; interaction; conscious attention; enthusiasm; video game addiction; uses and gratifications theory; cultivation theory 


\section{Introduction}

\section{Background}

Video games are one of the most popular forms of leisure activities, especially for youth (as well as other age groups) across the world [1]. The video gaming industry has come a long way since first video game, Atari, which was launched in 1972 [2]. Video game engagement has surpassed other forms of new media such as music and television owing to the rapid development of the digital gaming industry [3]. It has been estimated that digital gaming revenues rose to US $\$ 137.9$ billion, with approximately 2.3 billion gamers worldwide by the end of 2018. With the rise of video gaming activities, the risk of video gaming addiction has also increased [4]. Excessive use of web-based and offline video gaming affects the gamers' physical health and has an impact on their psychological well-being [5]. Video game addiction can cause gamers to develop a range of issues such as aggression and depression $[6,7]$, poor academic performance $[8,9]$, declining relations with friends and families [10,11], insomnia [12], and even self-harm $[13,14]$.

The literature on video game engagement has identified various factors that affect video gaming addiction. Studies on demographics have identified that males, young age, singles (relationship), etc are more likely to develop video game addiction [15]. Increased monetary spending on video gaming activities is positively correlated with video game addiction alongside other factors such as the presence of heightened family resentment among gamers and an increase in the average time spent on gaming activities [16]. With respect to psychographics, the factors that predict video game addiction are depression and sociability [17], hypercompetitiveness and psychological absorption [18], and dysfunctional impulsivity [19], thereby reducing extraversion, agreeableness, emotional stability, and attractiveness [20]. Increased video game engagement and maladaptive coping has helped identify individuals at risk of transitioning into video game addiction [21].

Likewise, the phenomenon of video game engagement has been investigated in different studies across multiple application areas. For instance, Abbasi et al [22] reported how gender differences variably influence video game engagement. Gabriel et al [23] reported that rich game experiences enhance engagement in video games. Additionally, Skoric et al [24] revealed that more addicted gamers perform poorly in academic assessments. Another study found that video game addiction affects mental health, causing depression, stress, and anxiety, but video game engagement is only linked to anxiety [21]. Video game engagement has been found to have no adverse effects on gamers' well-being [25,26], and several studies have differentiated addiction and engagement since they both result in different behavioral outcomes [27,28]. Although there are many studies on video game addiction, the research investigating the potential determinants of video game addiction through consumer video game engagement elements (eg, dedication, enthusiasm, conscious attention, absorption, social connection, interaction) remains limited.

\section{Study Aims and Rationale}

The purpose of this study was to expand the existing research by evaluating video game addiction from the lens of video game engagement. Our primary focus in this study was to evaluate whether different dimensions of consumer video game engagement play a role in predicting video game addiction. Our study will contribute to the literature in a number of ways. First, prior studies have not accounted for engagement factors that lead to addiction [1,28,29]. Our study adds value to this overarching literature as we uncover how engagement factors influence addiction in video games. Second, this study extends the application of Uses and Gratifications Theory (UGT) as studied in media, video game, and social media [30,31] and Cultivation Theory toward developing a theoretical model that explains the role of video game engagement dimensions in predicting video game addiction. We applied UGT to video game engagement factors (conscious attention, absorption, social connection, dedication, enthusiasm, and interaction), which give rise to a cultivation effect owing to increased engagement in video game play, resulting in video game addiction. Third, prior studies considered video game addiction as a second-order construct, but its specification and validation as a reflective-formative construct remains nebulous [32]. Considering this limitation, we add to video game addiction studies literature by specifying and validating video game addiction's construct as a reflective-formative construct.

\section{Theoretical Underpinning}

We explored the theoretical framework informing our understanding of the different dimensions of consumer engagement and video game addiction. Different theories associated with motivation, communication, and media were used to establish the theoretical framework for this research. This research takes its theoretical underpinning from the Cultivation Theory and UGT [33,34].

\section{UGT}

The principle of UGT was coined in the early 1940s. This theory came into the light to answer some questions raised concerning traditional mass communication. This theory emphasizes that media is used to satisfy a user's various needs, which motivates them to use that media $[35,36]$. This theory has been extensively applied to comprehend the motivation underlying media usage [37]; particularly, video games [38]. UGT is one of the most popular theories applied to assess the underlying motivation of users that engage in video gameplay [39]. With the high emphasis on video game engagement, UGT could provide a new perspective toward understanding video game addiction.

UGT consists of 3 constructs: (1) achievement, (2) enjoyment, and (3) social interaction. Achievement in the context of gaming can be defined as the yearning to achieve power and rewards as well as the desire to perform better in comparison to other gamers [40]. Sherry et al [39] found that challenge is the biggest motivation for playing video games as players are tempted to move through different stages quickly to complete the challenges [41]. In contrast, hardcore gamers who play video games with dedication [42] are inclined to preoccupy themselves with social comparison to flaunt their gaming achievements [43]. Enjoyment 
in the context refers to inherent pleasure derived from accomplishing the tasks [40], and it plays a major role when it comes to assessing an individual's desire to use a specific information system [44]. Social interaction in web-based gaming opens new channels of communication since gamers have an opportunity to socialize and cultivate existing or new relationships. Web-based games, therefore, provide an avenue to gamers, especially those who experience loneliness and low self-esteem, thus supporting individual desire to play video games [45]. Similarly, the UGT perspective accentuates the self-indulgent needs and interests that influence the motivation to engage in digital games [46]. Thus, UGT appears to be a relevant theory for this research since video game players actively indulge in video games, thereby leading to video game addiction.

\section{Cultivation Theory}

The explanation of mass media as cultivation was introduced by Gerbner [47]. The Cultivation Theory uncovers how mass media shapes the perceptions of people [48]. The Cultivation Theory suggests that exposure to media influences viewers' interpretation of reality [49]. Research has already demonstrated this phenomenon by investigating individuals' social settings and observing changes in people's attitudes and social norms [50,51]. Therefore, the media carries the capacity to enculturate the masses to adapt to the changing environment around them [52].

The Cultivation Theory provides a wide lens through which long-term effects of media can be examined. The Cultivation Theory has mostly been applied to traditional forms of media such as television. Aligned with the Cultivation Theory assumptions with respect to television (similarly, if this concept is applied to video gaming), this theory posits that through continuous exposure to the video gaming world, player's views of his real-world will become more similar to that of his gaming world [53]. For that purpose, Van Mierlo and Van den Bulck [54] argued that video games have become so authentic that they have started to mirror reality, thereby making cultivation possible [34]. Hence, video game players engage with different forms of synthetic media such as in-game challenges, stories, and characters, and this involvement in the video games is associated with concentrated attention [23], because of which the game player identifies himself with the role-played character and creates a visually epitomized virtual identity [55]. Thus, video games have started resembling reality, enabling the cultivation of an immersive reality [56]. Seah and Cairns [57] have also reported that the more immersed a gamer becomes, the immersion may lead to video game addiction.

\section{Consumer Video Game Addiction}

The massive popularity of video games has significantly changed the gaming industry as it is one of the most booming entertainment businesses [58]. Several studies have documented the risks and effects of video game addiction. A recent meta-analytic review, including 136 articles with 130,000 participants from both Eastern and Western cultures, found that video game addiction is likely to cause anxiety, depression, social phobia, and scholastic decline [59]. The study suggests that harmonious passion and obsessive passion predict different ways to engage in massively multiplayer online role-playing game (MMORPG). The study further confirms that passion is a valuable paradigm to recognize diverse motivational patterns expressed by MMORPG players [60]. Wittek et al [61] posit that video game addiction has a negative relationship with conscientiousness and a positive association with neuroticism. Hull et al [17] report that the social features of video gaming, distortion of time perceptions, and happiness levels significantly predict video game addiction. Apart from this, video game addiction is also reported to be associated with lower psychological functioning, unsatisfactory academic performance, increased alcohol consumption, sleep deprivation, aggression and depression, social disconnectedness, and increased caffeine consumption [17,62-64].

\section{Consumer Video Game Engagement}

Consumer engagement is the interaction between a customer and an organizational entity through different channels whereas engagement in consumer game-playing is a concept that signals task-oriented consumer behavior in the game setting [65]. Video games are purposely intended to draw the attention of its consumer base to ensure that video game consumers will evolve into frequent game players $[66,67]$. This appeal is primarily engendered by the engaging experiences video games are intended to deliver [68]. These experiences are coined as playful video game consumption experience and have led to behavioral changes among its consumer base [69].

Previous studies deem engagement as a multidimensional construct that comprises of subconstructs such as immersion [70,71], presence [72], flow [73], fun [74], enjoyment [72,75], fun [74], and absorption [76]. Hollebeek et al [77] also suggest that the construct engagement is a multidimensional concept comprising of 3 dimensions: (1) cognitive, (2) emotional, and (3) behavioral. Researchers also accentuate that different dimensions of consumer engagement are interrelated [78]. For instance, Brodie et al [79] identified that emotional involvement can increase other video game engagement dimensions (ie, cognitive and behavioral).

Bouvier et al [41] identified 4 types of gaming engagement behaviors, that is, (1) environment-directed behavior, (2) social-directed behavior, (3) self-directed behavior, and (4) action-directed behavior. They further explain that environment-directed behavior refers to the participation of players oriented toward the setting or the ecological backdrop in the game. In contrast, social participation alludes to the social links present in the game. Games offer players the opportunity to develop and foster their social relationships with other players, thereby establishing social links in the virtual environment. Self-directed behavior refers to the relationship between players and their virtual character. For instance, we often see players have a preference to personalize their virtual presence such as customizing their avatar or opting for accessories for reasons other than performance. Lastly, action-directed behavior refers to goal-directed measures taken by players in different in-game situations. Players act for many reasons such as seeking to quickly move between stages, gain different experiences, and accomplish challenges. 
Abbasi et al [22] report multidimensionality within video game engagement and demonstrates that the construct comprises of 6 dimensions, that is, (1) dedication, (2) absorption, (3) conscious attention, (4) social connection, (5) enthusiasm, and (6) interaction. This study aims to determine which of these dimensions can result in addiction to video games, which may provide empirical evidence in this sector.

\section{Game Addiction and Game Engagement: Are They Similar or Distinct?}

Video game addiction and video game engagement were previously used interchangeably [24]. However, recently, these 2 terms have been considered as 2 separate entities [15]. Distinguishing gaming addiction from gaming engagement has been a challenge for researchers [15]. Several studies have approached this concern by differentiating game addiction from game engagement; first, Charlton and Danforth [80] showed that a gaming addict group spends twice the hours as a highly engaged gamers group in playing games each week. In another study, game addiction scores were negatively related to emotional stability; however, gaming engagement scores remained unchanged [20]. Charlton and Danforth [80] also reported a considerable difference between video game addiction and video game engagement. They posited that addiction should not be confused with active engagement as addiction includes withdrawal symptoms, that is, anxiety and guilt. Brunborg et al [15] also distinguished video game addiction from video game engagement through a self-administered questionnaire. In their study, engaged gamers showed salience and mood modification, whereas addicted gamers exhibited anxiety, apprehension, touchiness, and isolation. The key differentiation between addiction and engagement included the range of adverse consequences experienced by the consumers [81,82]. Video game addiction is possibly linked to a range of adverse effects such as mental, physical, and social deterioration, but this is not the case in high engagement [82]. Video game addiction is mainly linked with growing signs of stress, anxiety, and depression [83].

\section{Dimensions of Consumer Video Game Engagement}

Dedication is the affective commitment of players toward video games [84]. Kallio et al [85] reported that some gamers play for pleasure, whereas others play to form a connection with the game. Players who are committed and loyal spend more time playing social games, ensuring that they are dedicated to the video game [85]. Similarly, it has been found that hardcore gamers on average play more than an hour per day [86,87], spending most of their leisure time dedicated to gaming activities $[42,88]$. On the contrary, casual gamers spend less time playing games since they play in small bursts and have a casual attitude toward gaming [89]. Conrad [90] found that games tended to be addictive if played for more extended periods. Griffiths [91] assessed the consequences of excessive gaming and found that players experienced behavioral addiction symptoms, including salience, mood modification, and tolerance. Van Rooij et al [92] reported that teenagers who spend an average of 55 hours per week on gaming tended to develop depressive moods, loneliness, social anxiety, and negative self-esteem. On the basis of the abovementioned relationships, we posit the following hypothesis:

\section{H1: Dedication positively predicts video game addiction in a video game player.}

Absorption is defined as the degree of involvement and immersion in a given activity [93]. Csikszentmihalyi [94] reports that absorption in an activity is regarded as "flow experience," and video games encourage a state of flow and learning in gamers [95]. Players in this state immerse themselves and become absorbed in their activity. This way, they become oblivious to their surroundings, which narrows their focus of situation awareness. De Pasquale et al [96] reported that excessive absorption of video games leads to neglecting the surrounding environments. Furthermore, when trying to curb video game playing, absorption has been correlated with anxiety, irritability, and emotional fragility. Excessive video game absorption is unhealthy and can potentially lead to addiction $[57,97]$. Based on these relationships, we posit the following hypothesis:

\section{H2: Absorption in video games significantly predicts video game addiction in a video game player.}

Conscious attention is the attention and time allocated toward a given activity [98-100]. Consciousness is a "complex system that has evolved in humans for selecting information from this profusion, processing it, and storing it" and determines "what to pay attention, how intense, and for how long" [101]. In the state of flow, an individual experiences conscious processes followed by attentional processes, which require concentration and unilateral focus [101]. The individual operates at full capacity [102], devotes full attention to achieve goals [94], and goes through the distortion of temporal experiences [101]. Haladjian and Montemayor [103] report that conscious attention lets us intermingle with our complicated surroundings and enables us to remain involved in the task at hand. Similarly, consistent, conscious attention over a considerable period makes the player more absorbed. Therefore, conscious attention and video game consumption carry addictive tendencies and lead to addiction $[57,97]$. We further posit the following hypothesis:

\section{H3: Conscious attention predicts video game addiction in a video game player.}

Social connection is the relationship people have with other individuals or groups [104]. Web-based gamers may shape meaningful relationships through social connections made during interactive gameplay [105]. Digital games can often create unrestrained social environments where players connect and form connections [106,107]. According to the augmentation hypothesis, people with an active social life also endeavor to build social ties in the virtual world [108]. Sioni et al [109] reported that video game addiction is very likely to occur owing to social phobia. Cole and Griffiths [110] suggested that people often try to develop long-term friendships based on their gaming experiences, and this socialization aspect tends to keep them motivated to continue playing. On the contrary, Peters and Malesky Jr [111] reported that gamers looking for social connections in gaming contexts may struggle to form tangible social connections outside gaming environments. It has additionally been found that people who cannot develop real-life 
connections tend to develop web-based virtual connections, and people who have social anxiety as well as depression also tend to use web-based media, which has been associated with addictive symptoms [15]. Accordingly, we put forward the following hypothesis:

\section{H4: Social connections significantly predict video game addiction in a video game player.}

Enthusiasm is defined as the extent of eagerness and interest toward a given activity $[104,112]$. Enthusiasm is the inner driver that motivates individuals to play video games. Enthusiasm encourages individuals to overcome obstacles to reach higher levels in games [113]. Griffiths [91] adds that one can differentiate between enthusiasm and addiction since enthusiasm contributes to life, whereas addiction takes away life. Although enthusiasm and addiction can most certainly be different phenomena and experiences, it can be fair to conclude that excessive enthusiasm for a particular video game can potentially lead to addiction. Hence, we put forward the following hypothesis:

Figure 1. Study conceptual model.

\section{H5: Enthusiasm significantly predicts video game addiction in a video game player.}

Interactions reflect the degree of involvement that individuals and other entities have in virtual game settings. So et al [112] report that interactions signify how players interact with synthetic game components. Interaction is positively correlated with consumer video game engagement [114] since interactive experiences influence the degree of consumer engagement $[115,116]$. Weibel et al [107] reported that gamers actively seek interaction with other players; this social element leads to increased duration of gameplay and heightened engagement levels. This has the potency to result in video game engagement [117]. Griffiths [91] reports that excessive interaction between human-machine components can influence different aspects of addiction, including mood, tolerance, withdrawal symptoms, etc. Similarly, it has been found that social interaction is one of the triggers of addiction [118]. Thus, we put forward the following hypothesis (see Figure 1 for the full study model and hypotheses):

\section{H6: Interaction positively predicts video game addiction in a video game player.}

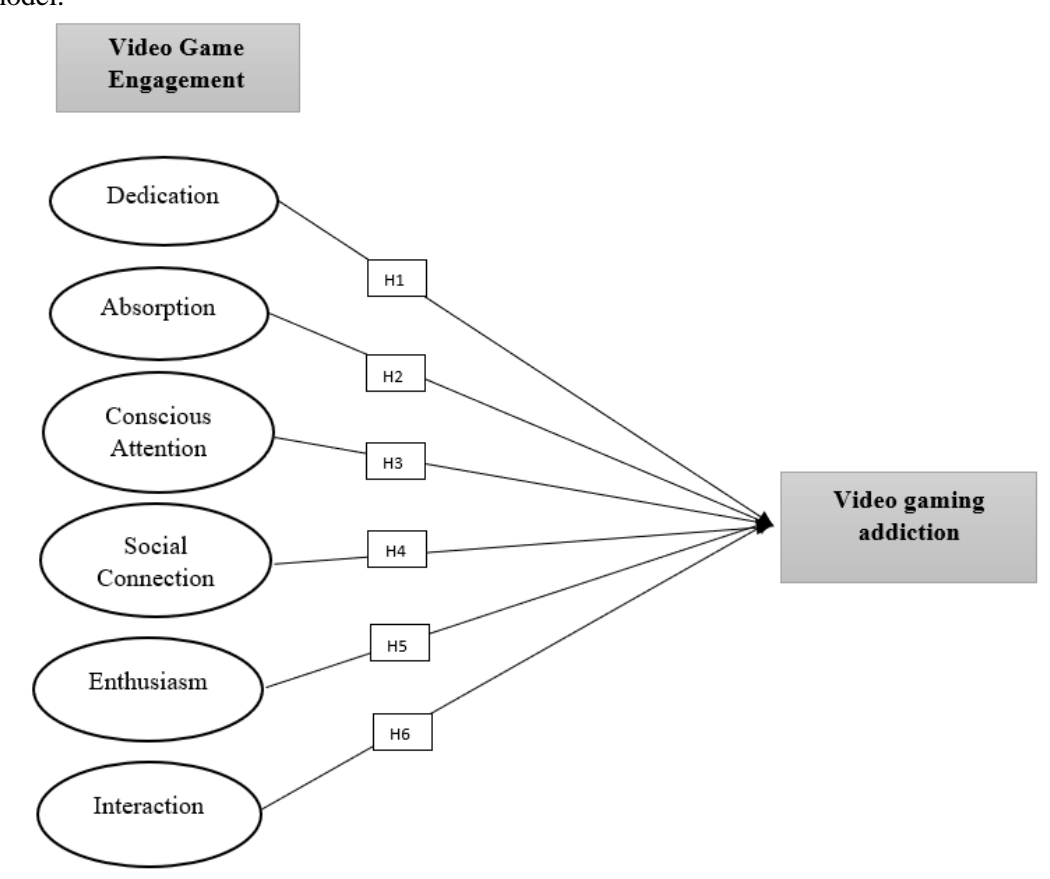

\section{Methods}

\section{Study Design}

This study was quantitative and cross-sectional. This approach is relatively fast in obtaining responses to develop or validate new theories [119]. Following this approach, we required a survey to collect the data (Multimedia Appendix 1). Hence, we designed the survey into 2 units: the first unit of the questionnaire included the participants' demographic profiles regarding their video gaming consumption patterns. Questions in the second unit were related to the constructs of the theoretical model, including engagement and addiction. As previously mentioned, video gaming engagement comprised 6 dimensions, whereas video gaming addiction was formulated as 7 dimensions of the second-order construct. The items measuring the video game engagement dimensions were adapted [22,28,120]. The items assessing the construct of video game addiction were adapted [121]. The questionnaire items were evaluated on a 5-point Likert Scale from 1 (strongly disagree) to 5 (strongly agree). Hair Jr et al [122] recommended applying the $\mathrm{G}^{*}$ power analysis tool when the sample frame is unknown. Using the power analysis, we set the input parameters as follows: effect size $\left(f^{2}\right)=0.15, \alpha$ error probability $=.05$, power $(1-\beta$ error probability $)=.95$, and predictors $=6$, which calculated the total sample size of 146 for the study model to conduct partial least squares-structural equation modeling (PLS-SEM) analyses. To sample the participants, we considered purposive sampling owing to its popularity in social sciences and the ability to obtain a sample that can represent the population [123]. 
This study was carried out among gamers who play in gaming zones (a gaming zone is a venue or an entertainment service provider, which facilitates users to play competitive games in groups to compete with each other) [124] or in organized tournaments at institutions located in the twin cities of Islamabad and Rawalpindi. The only inclusion criterion was if they play video games (eg, Counter Strike-Global Offensive, PlayerUnknown's Battlegrounds, Call of Duty, Fortnite) daily for a minimum of 1 hour. The main reason for selecting 1 hour as the minimum criterion for sample selection was that playing video games in gaming zone/cafe is an expensive activity in low-income countries such as Pakistan because gamers are charged about PKR 300-500 (US \$1.5-\$3) per hour/session, whereas the per capita income in Pakistan is only US $\$ 1516$. Second, parents are authoritarian in Pakistan and they may limit their children from longer screen time as the age bracket from 15 to 20 years is considered as the prime age for education and career development [125]. Third, gamers older than 21 years could be engaged in some jobs with their studies to meet their needs and wants.

While collecting the data, we carefully recruited gamers who played Counter Strike-Global Offensive, PlayerUnknown's Battlegrounds, Call of Duty, and Fortnite and proceeded for data collection. Using the self-administered approach, we distributed 250 questionnaires and 190 were returned. We assessed the data quality and removed incomplete and biased responses (ie, using the particular response pattern) (Multimedia Appendix 2). Finally, we had 176 valid responses to continue with data analyses; see Table 1 for participants' details.

The structural equation modeling approach was applied for analysis, which is a well-rounded multivariate statistical analysis approach [126,127]. Structural equation modeling appears to be the most suitable approach because the research variables consist of both formative and reflective constructs [128]. For PLS-SEM analysis, WarpPLS software by Kock [129] was employed in this research. 
Table 1. Characteristics of the participants $(\mathrm{N}=176)$.

\begin{tabular}{|c|c|}
\hline Characteristics & Values, $\mathrm{n}(\%)$ \\
\hline \multicolumn{2}{|l|}{ Gender } \\
\hline Male & $128(72.7)$ \\
\hline Female & $48(27.3)$ \\
\hline \multicolumn{2}{|l|}{ Age (years) } \\
\hline $15-20$ & $53(30.1)$ \\
\hline $21-25$ & $123(69.9)$ \\
\hline \multicolumn{2}{|l|}{ Education } \\
\hline Higher secondary education & $45(25.6)$ \\
\hline Bachelor's & $65(36.9)$ \\
\hline Master's & $66(37.5)$ \\
\hline \multicolumn{2}{|c|}{ Expenditures on video games daily (exchange rate: 1 USD=PKR 153.314 in December 2019) } \\
\hline PKR 0-500 & $88(50)$ \\
\hline PKR 500-1000 & $58(33)$ \\
\hline PKR 1000-5000 & $20(11.4)$ \\
\hline Above PKR 5000 & $10(5.7)$ \\
\hline \multicolumn{2}{|l|}{ Device used for gaming } \\
\hline Play station & $59(33.5)$ \\
\hline Cybercafé & $45(25.6)$ \\
\hline Xbox & $26(14.8)$ \\
\hline Others & $46(26.1)$ \\
\hline \multicolumn{2}{|l|}{ Games played the most } \\
\hline Counter Strike-Global Offensive & $55(31.3)$ \\
\hline PlayerUnknown's Battlegrounds & $29(16.5)$ \\
\hline Call of duty & $68(38.6)$ \\
\hline Fortnite & $24(13.6)$ \\
\hline \multicolumn{2}{|c|}{ Time spent on video games daily (hours) } \\
\hline $0-1$ & $72(40.9)$ \\
\hline $1-2$ & $65(36.9)$ \\
\hline $2-4$ & $39(22.2)$ \\
\hline
\end{tabular}

\section{Assessing the Reflective Constructs}

In the measurement model's assessment, first, the reflective constructs were assessed in which the construct's outer loadings, Cronbach alpha, composite reliability, and convergent validity were evaluated. According to the criteria, the outer loadings should be greater than at least 0.40 , the Cronbach alpha value should be greater than .70 , the composite reliability should be greater than 0.70 , and the convergent validity should be greater than $0.5[126,128]$. The values for all the measures met the benchmark, thereby ensuring the reliability and the validity of the constructs; hence, the measurement model of the reflective measures was satisfactorily fulfilled (Table 2).
Additionally, the discriminant validity was evaluated applying the Fornell and Larcker (1981) criterion. The criterion suggests that the square root of the average variance extracted of each dimension must be larger than its corresponding correlation coefficient. Heterotrait-monotrait ratio of correlations is another criterion that is the most recent and recommended validity test to assess the discriminant validity for reflective constructs [130]. The heterotrait-monotrait ratio of correlations values are deemed to be satisfactory if lower than 0.90 and best if lower than 0.85 . The results in Table 3 and Table 4 reported that discriminant validity had attained satisfactory values. 
Table 2. Measurement model: first-order constructs.

\begin{tabular}{cc}
\hline Scale, items & Loading \\
\hline Conscious attention & \\
Item 1 & 0.84 \\
Item 2 & 0.872 \\
Item 3 & 0.855 \\
Item 4 & 0.902 \\
Item 5 & 0.842 \\
Item 6 & 0.724
\end{tabular}

Absorption

0.93

.906

0.728

Item 1

0.838

Item 2

0.866

Item 3

0.895

Item 4

0.863

Item 5

0.802

Dedication

0.928

.903

0.72

Item 1

0.851

Item 2

0.863

Item 3

0.856

Item 4

0.842

Item 5

0.83

Enthusiasm

Item 1

0.688

Item 2

0.832

Item 3

0.844

Item 4

0.816

Item 5

0.771

Social connection

0.9

.833

0.75

Item 1

0.865

Item 2

0.871

Item 3

0.862

\section{Interaction}

$\begin{array}{ll}\text { Item 1 } & 0.832 \\ \text { Item 2 } & 0.878 \\ \text { Item 3 } & 0.866 \\ \text { Item 4 } & 0.858 \\ \text { Item 5 } & 0.827\end{array}$

Salience

Item 1

0.873

Item 2

0.872

Item 3

0.889

Tolerance

0.893

.82 


\begin{tabular}{|c|c|c|c|c|}
\hline Scale, items & Loading & Composite reliability & Cronbach alpha & Average variance extracted \\
\hline Item 3 & 0.837 & & & \\
\hline Mood modification & & 0.902 & .836 & 0.753 \\
\hline Item 1 & 0.859 & & & \\
\hline Item 2 & 0.862 & & & \\
\hline Item 3 & 0.883 & & & \\
\hline Relapse & & 0.913 & .857 & 0.778 \\
\hline Item 1 & 0.879 & & & \\
\hline Item 2 & 0.897 & & & \\
\hline Item 3 & 0.87 & & & \\
\hline Withdrawal & & 0.897 & .828 & 0.745 \\
\hline Item 1 & 0.831 & & & \\
\hline Item 2 & 0.908 & & & \\
\hline Item 3 & 0.848 & & & \\
\hline Conflict & & 0.912 & .855 & 0.775 \\
\hline Item 1 & 0.873 & & & \\
\hline Item 2 & 0.896 & & & \\
\hline Item 3 & 0.872 & & & \\
\hline Problem & & 0.952 & .924 & 0.869 \\
\hline Item 1 & 0.928 & & & \\
\hline Item 2 & 0.958 & & & \\
\hline Item 3 & 0.909 & & & \\
\hline
\end{tabular}

Table 3. Discriminant validity using Fornell and Larcker criterion.

\begin{tabular}{|c|c|c|c|c|c|c|c|c|c|c|c|c|c|}
\hline Dimension & $\begin{array}{l}\text { Con- } \\
\text { scious at- } \\
\text { tention }\end{array}$ & $\begin{array}{l}\text { Absorp- } \\
\text { tion }\end{array}$ & $\begin{array}{l}\text { Dedica- } \\
\text { tion }\end{array}$ & $\begin{array}{l}\text { Enthusi- } \\
\text { asm }\end{array}$ & $\begin{array}{l}\text { Social } \\
\text { connec- } \\
\text { tion }\end{array}$ & $\begin{array}{l}\text { Interac- } \\
\text { tion }\end{array}$ & Salience & $\begin{array}{l}\text { Toler- } \\
\text { ance }\end{array}$ & $\begin{array}{l}\text { Mood } \\
\text { modifi- } \\
\text { cation }\end{array}$ & $\begin{array}{l}\text { Re- } \\
\text { lapse }\end{array}$ & $\begin{array}{l}\text { With- } \\
\text { draw- } \\
\text { al }\end{array}$ & $\begin{array}{l}\text { Con- } \\
\text { flict }\end{array}$ & $\begin{array}{l}\text { Prob- } \\
\text { lem }\end{array}$ \\
\hline $\begin{array}{l}\text { Conscious atten- } \\
\text { tion }\end{array}$ & 0.841 & & & & & & & & & & & & \\
\hline Absorption & 0.500 & 0.853 & & & & & & & & & & & \\
\hline Dedication & 0.402 & 0.538 & 0.849 & & & & & & & & & & \\
\hline Enthusiasm & 0.439 & 0.496 & 0.544 & 0.792 & & & & & & & & & \\
\hline $\begin{array}{l}\text { Social } \\
\text { connection }\end{array}$ & 0.313 & 0.440 & 0.275 & 0.601 & 0.866 & & & & & & & & \\
\hline Interaction & 0.487 & 0.454 & 0.405 & 0.573 & 0.663 & 0.853 & & & & & & & \\
\hline Salience & 0.402 & 0.510 & 0.462 & 0.566 & 0.527 & 0.565 & 0.878 & & & & & & \\
\hline Tolerance & 0.336 & 0.456 & 0.373 & 0.479 & 0.435 & 0.435 & 0.614 & 0.858 & & & & & \\
\hline $\begin{array}{l}\text { Mood modifica- } \\
\text { tion }\end{array}$ & 0.323 & 0.310 & 0.239 & 0.403 & 0.300 & 0.322 & 0.395 & 0.461 & 0.868 & & & & \\
\hline Relapse & 0.248 & 0.379 & 0.288 & 0.401 & 0.288 & 0.265 & 0.499 & 0.413 & 0.587 & 0.882 & & & \\
\hline Withdrawal & 0.276 & 0.334 & 0.334 & 0.304 & 0.221 & 0.229 & 0.397 & 0.424 & 0.535 & 0.736 & 0.863 & & \\
\hline Conflict & 0.365 & 0.201 & 0.248 & 0.212 & 0.146 & 0.133 & 0.241 & 0.291 & 0.447 & 0.392 & 0.535 & 0.88 & \\
\hline Problem & 0.265 & 0.357 & 0.353 & 0.296 & 0.195 & 0.217 & 0.333 & 0.415 & 0.286 & 0.366 & 0.374 & 0.426 & 0.932 \\
\hline
\end{tabular}


Table 4. Discriminant validity using heterotrait-monotrait ratio of correlations. ${ }^{a}$

\begin{tabular}{|c|c|c|c|c|c|c|c|c|c|c|c|c|c|}
\hline & $\begin{array}{l}\text { Con- } \\
\text { scious at- } \\
\text { tention }\end{array}$ & $\begin{array}{l}\text { Absorp- } \\
\text { tion }\end{array}$ & $\begin{array}{l}\text { Dedica- } \\
\text { tion }\end{array}$ & $\begin{array}{l}\text { Enthusi- } \\
\text { asm }\end{array}$ & $\begin{array}{l}\text { Social } \\
\text { connec- } \\
\text { tion }\end{array}$ & $\begin{array}{l}\text { Interac- } \\
\text { tion }\end{array}$ & Salience & $\begin{array}{l}\text { Toler- } \\
\text { ance }\end{array}$ & $\begin{array}{l}\text { Mood } \\
\text { modifi- } \\
\text { cation }\end{array}$ & $\begin{array}{l}\text { Re- } \\
\text { lapse }\end{array}$ & $\begin{array}{l}\text { With- } \\
\text { draw- } \\
\text { al }\end{array}$ & $\begin{array}{l}\text { Con- } \\
\text { flict }\end{array}$ & $\begin{array}{l}\text { Prob- } \\
\text { lem }\end{array}$ \\
\hline Absorption & 0.550 & & & & & & & & & & & & \\
\hline Enthusiasm & 0.499 & 0.571 & 0.625 & & & & & & & & & & \\
\hline $\begin{array}{l}\text { Social connec- } \\
\text { tion }\end{array}$ & 0.357 & 0.507 & 0.316 & 0.715 & & & & & & & & & \\
\hline Interaction & 0.537 & 0.504 & 0.448 & 0.649 & 0.763 & & & & & & & & \\
\hline Salience & 0.455 & 0.580 & 0.526 & 0.668 & 0.625 & 0.645 & & & & & & & \\
\hline $\begin{array}{l}\text { Mood modifica- } \\
\text { tion }\end{array}$ & 0.371 & 0.355 & 0.275 & 0.480 & 0.359 & 0.370 & 0.468 & 0.558 & & & & & \\
\hline Relapse & 0.278 & 0.430 & 0.327 & 0.470 & 0.341 & 0.301 & 0.584 & 0.492 & 0.692 & & & & \\
\hline Withdrawal & 0.314 & 0.387 & 0.385 & 0.363 & 0.267 & 0.268 & 0.475 & 0.516 & 0.647 & 0.876 & & & \\
\hline Conflict & 0.410 & 0.227 & 0.282 & 0.254 & 0.173 & 0.152 & 0.281 & 0.347 & 0.529 & 0.458 & 0.634 & & \\
\hline Problem & 0.290 & 0.390 & 0.386 & 0.339 & 0.221 & 0.237 & 0.374 & 0.476 & 0.325 & 0.411 & 0.427 & 0.480 & \\
\hline
\end{tabular}

${ }^{\mathrm{a}}$ Heterotrait-monotrait ratio of correlations: good if $<0.90$; best if $<0.85$.

\section{Assessing the Formative Constructs}

To create the second-order formative construct, that is, video game addiction, we employed the two-stage approach of Becker et al [131] to calculate the latent variable scores of first-order reflective constructs of salience, problem, withdrawal, mood modification, relapse, conflict, and tolerance. Afterwards, the latent variables scores were used to create the video game addiction construct as specified in Figure 1 and Figure 2. The quality checks for assessing the formative construct were quite different from those for assessing reflective constructs. Assessing the formative construct for reliability and validity, researchers suggest to use variance inflation factor (the values should be $<5$ or $<3.3$, the most restrictive one) and calculate the weights and its significance $[29,132]$. We analyzed the formative construct and reported the results in Table 5, thereby showing the formative construct's validity. It met the threshold values, that is, variance inflation factor values are lower than 3.3 and indicator weights are significant. 
Figure 2. The empirical-based study model.

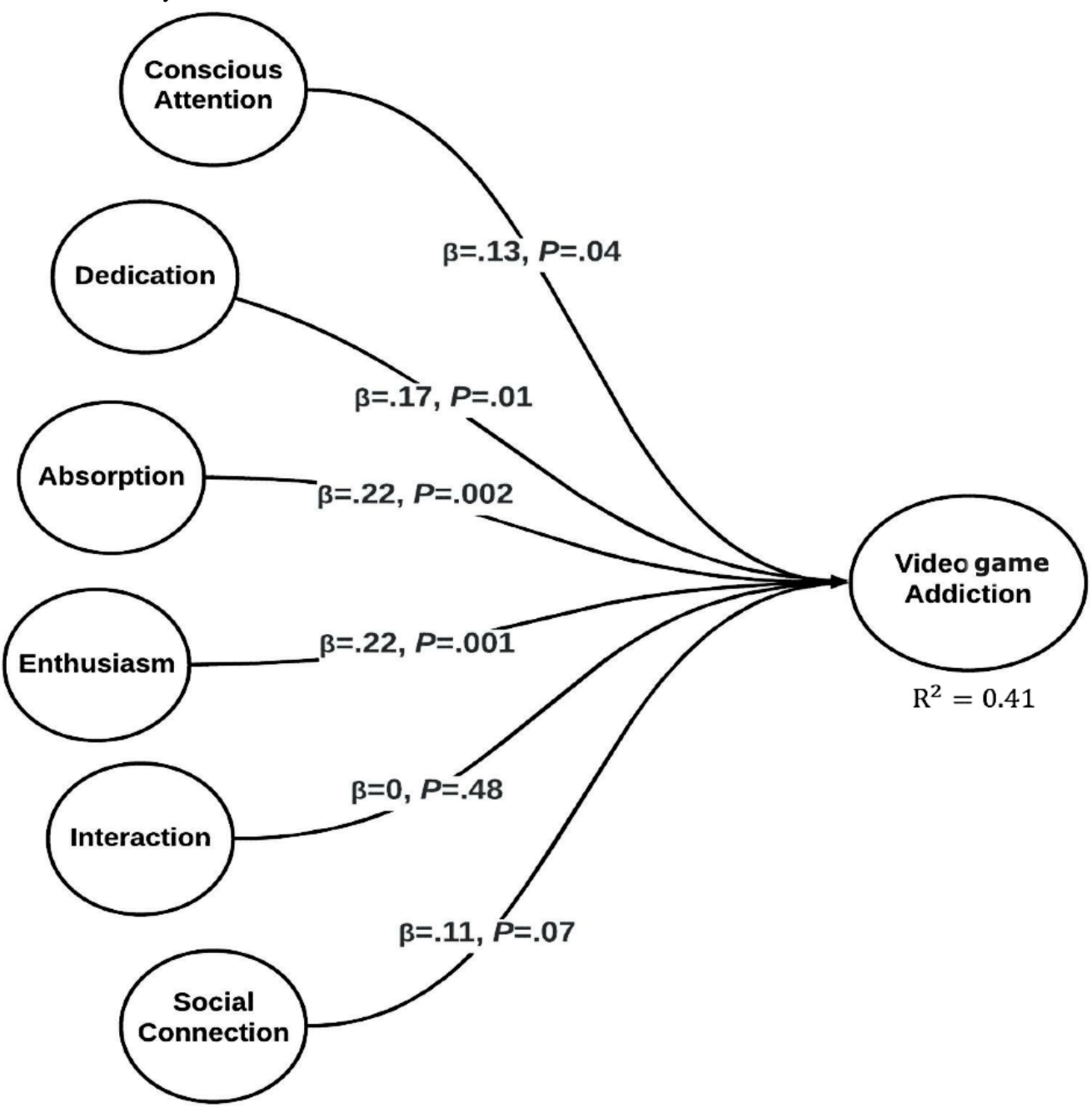

Table 5. Evaluation of the formative measurement model on the second-order constructs of video game addiction.

\begin{tabular}{lllll}
\hline Items & Scale type & Weights & Significance & Full collinearity \\
\hline Salience & Formative & 0.188 & .005 & 2.383 \\
Tolerance & Formative & 0.195 & .004 & 1.987 \\
Mood modification & Formative & 0.205 & .003 & 1.892 \\
Relapse & Formative & 0.223 & .001 & 2.867 \\
Withdrawal & Formative & 0.222 & .001 & 2.744 \\
Conflict & Formative & 0.178 & .008 & 1.780 \\
Problems & Formative & 0.167 & .01 & 1.485 \\
\hline
\end{tabular}

\section{Results}

PLS-SEM analysis was conducted in 2 stages comprising the measurement model and structural model assessment. Once the reliability and validity of the reflective and formative constructs were ensured, researchers recommended evaluating the structural model through path coefficients, effect size, $t$ value and calculated the predictive relevance, that is, $\mathrm{Q}^{2}$ and $\mathrm{R}^{2}$ coefficient value for the endogenous constructs $[28,29,128]$. WarpPLS was used to validate the hypotheses. For $\mathrm{H} 1$, the analysis results revealed a significant relation with $\mathrm{B}=0.129, P=.04$, and $t$ statistics of 1.76 with $f^{2}=0.056$. Hence, $\mathrm{H} 1$ was supported. For $\mathrm{H} 2$, the results revealed a significant impact of absorption on the consumer video game addiction with $\mathrm{B}=0.215, P=.002$, and $t$ statistics of 2.98 with $f^{2}>=0.113$. For $\mathrm{H} 3$, the results were supported with $\mathrm{B}=0.166, P=.01$, and $t$ statistics of 2.27 with $f^{2}=0.079$. For $\mathrm{H} 4$, the hypothesis was also supported with $\mathrm{B}=0.220, P=.001$, and $t$ statistics of 3.05 with $f^{2}=0.118$. For H5, the analysis results revealed that the relationship between both the constructs was insignificant with $\mathrm{B}=0.107, P=.08$, and $t$ value of 1.44 . Hence H5 was rejected. Similarly, interaction with consumer video game addiction was also insignificant with 
$\mathrm{B}=-0.003, P=.49$, and $t$ value of 0.04 . We also calculated the $\mathrm{R}^{2}$ and $\mathrm{Q}^{2}$ for the endogenous construct, that is, video game addiction, which resulted in $R^{2}=0.409$ and $Q^{2}=0.413$. Our results showed that the study model has sufficient explanatory capacity and predictive relevance. Figure 2 and Table 6 show the results of the structural model assessment.

Table 6. Structural model assessment.

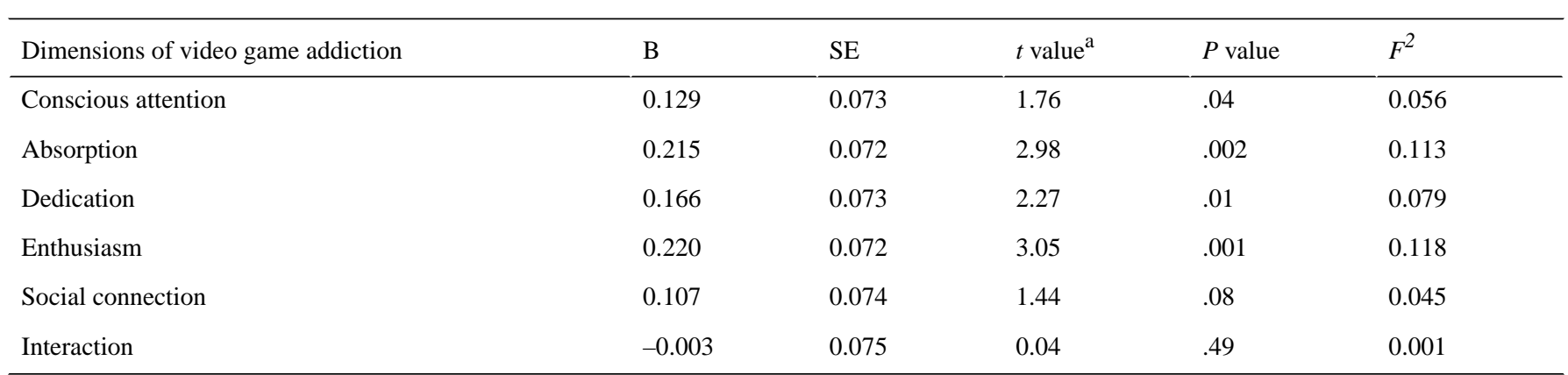

${ }^{\mathrm{a}}$ Degree of freedom not provided because WarpPLS software was used.

\section{Discussion}

\section{Principal Findings}

In this study, we intended to empirically test the theoretical model illustrating the different dimensions of video game engagement, that is, (1) dedication, (2) absorption, (3) conscious attention, (4) social connection, (5) enthusiasm, and (6) interaction in a digital game, that predict consumer video game addiction. The underlying constructs were supported by theoretical underpinnings from the Cultivation Theory [47] and UGT [37]. Our results indicated that 4 out of 6 dimensions (ie, dedication, absorption, conscious attention, and enthusiasm in consumer video game engagement) significantly predict consumer video game addiction; however, social connection and interaction in consumer video game engagement had no significant effect on video game addiction.

Previous research suggests various personal, emotional, and psychological needs that contribute to overindulgence in video gameplay [133,134]. It has also been reported that gaming environments provide safe and interactive avenues for individuals who experience social disconnection or isolation in real-life environments [15]. This is also a means of open interaction for such individuals since the consequences for actions in gaming environments are minimal; therefore, the fear of interaction subsides [107]. Peer pressure in social groups is also a significant reason for excessive indulgence in video games. The media hype of video games have led some people to assume that behavioral problems are triggered by video games and contribute to video game addiction [135]. Further, rigorous advertising on different media plays a role in convincing individuals to play video games and experience instant gratification and other psychological needs. Cultivation Theory unravels the grounds explaining why individuals are addicted to video gaming, primarily because increased exposure to video games carries negative consequences. Such results are consistent with those reported in previous literature, where addiction contributes to different problems in the individual's personality and social life [136].

H1 showed the relationship between dedication and the resulting video game addiction. The results supported that there is a positive relationship between the 2 constructs. They showed that dedicated players (and attached) to the gameplay for long hours put in more energy, commitment, and loyalty than casual players [85,137]. H2 showed the relationship between absorption and video game addiction. Our results supported the positive relationship between the 2 constructs-consistent with that reported in previous literature [138]. They indicated that absorption leads to deep involvement in the game, which results in neglecting the surrounding environments and resulting in various problematic behaviors [96]. H3 showed the relationship between conscious attention and video gaming addiction. The results supported this testable statement (showed a positive effect between conscious attention and video gaming addiction). Through conscious attention, players tend to develop deep concentration [101], which results in neglecting the surroundings [103], leading toward video game addiction. H4 showed the relation between enthusiasm and video gaming addiction. As reported previously by Seay and Kraut [139], we found that excessive consumption of entertaining electronic gadgets can create interference in the real lives of the individuals.

Social connection and interaction were hypothesized to positively affect video game addiction ( $\mathrm{H} 4$ and $\mathrm{H} 6$, respectively). However, both the constructs had no significant relationship with video game addiction. These results seem to contradict the prior literature [109,110,140-142]. Based on the context of Pakistan, this study is not in line with these 2 concepts. Pakistan, being a collectivist society, encourages people to interact socially, and excessive video gaming tends to make them socially isolated. The social connections developed during video gaming sessions seem to have little or no effect on video gaming addiction. The sense of isolation due to excessive use of technology has also been confirmed in different studies concerning internet usage [143,144]. This contradictory finding in our study opens a new door for future research as to why video gaming social connectedness does not predict video gaming addiction in Pakistan and whether the findings of this study can be applied to other contexts. We also concluded that the interaction does not predict video game addiction. Sedig and Parsons [114] report that video games are purposefully designed for a highly interactive experience. Although interactive video games lead to a more profound 
interest and increased engagement, they do not necessarily result in gaming addiction. Additional research is required to investigate this finding further.

\section{Theoretical Implications}

The results of this study contribute to the understanding of the Cultivation Theory in the context of video games, that is, video game addiction [145]. While the focus of Cultivation Theory has mainly been restricted to the effects of video-based media, for example, television and films, this research applies it in the context of video games, especially how video game engagement factors cultivate addiction in video game players. This expands the scope of the theory to media that is not merely passive but also interactive in video games. This may help future researchers understand how behaviors, especially negative ones, are influenced by video game material, that is, video game engagement dimensions. Similarly, this study also helps expand the scope of the UGT. It does this by exploring the different video game engagement factors comprising absorption, conscious-attention, dedication, enjoyment, and social interaction in video games as user's gratifications are derived from video game play. This study's conceptual model highlights factors that motivate users of pleasure-oriented information systems, specifically video games, to continue prolonged usage. Specifically, this study offers dedication, absorption, conscious attention, and enthusiasm as significant, positively impacting factors that lead to addiction. This adds another dimension to the understanding of video game addiction by combining cultivation theory, UGT, and these unique factors that lead to habit-building that turns into an addiction. Moreover, this study offers insight into the reasons underlying video game usage, mostly hedonic, and how it is reinforced due to a specific gameplay characteristic. In doing so, it helps highlight the reasons underlying engagement with pleasure-oriented information systems to construct a holistic conceptual model where usage is observed as a form of meeting certain needs (UGT) and shaping worldviews (cultivation theory). Previously, authors conceptualized and specified the gaming addiction construct as a reflective-formative construct, but its empirical validation remains nebulous to date [32]. Addressing this knowledge gap, we employ the hierarchical component model approach as recommended by Sarstedt et al [132] to operationalize, specify, and validate the construct of video game addiction as a reflective-formative construct.

\section{Practical Implications}

This study offers valuable insight for practitioners in game development, psychology, and social policy as well. First, an understanding of why consumers continue to use games up to the point of addiction can highlight factors that help make games engaging. This can be used to cultivate brand loyalty as game developers roll out updates of their games. Moreover, the insignificant correlation between social connections and video game addiction will help developers understand how social bonds may not facilitate engagement for specific regions such as Pakistan, in this case. At the same time, this information can also be used to curb factors that turn repeated or prolonged usage into a harmful addiction. This can help game developers ensure that they are producing games conducive to healthy usage to meet health care and social concerns. Similarly, these findings can be used by mental health practitioners who aim to find treatment solutions for video game addictions. By understanding the aspects of video game play that leads to addiction, these practitioners may be better able to prescribe changes to playing behavior and patterns to reduce addiction. In terms of policymaking, this study helps policymakers understand what aspects of video game playing lead to the development of problematic real-life behaviors that are considered unhealthy or are discouraged.

\section{Conclusion}

This study seeks to examine the individual effect of different dimensions of video gaming engagement on video game addiction. The findings of our study add value to the existing literature. The factors that lead to video gaming addiction can be empirically stated through the findings of this study. This research also provides valuable insights into the consumption pattern of video gamers. Future research directions could involve incorporating the psychographic mechanisms as moderators such as personality traits, values and attitudes, interests, lifestyles, and gender in understanding video game addiction [146]. Additionally, the theoretical model could be applied to investigate the antecedents of video gaming engagement, that is, the factors that cause people to engage in video gaming consumption and that video game interaction does not have a significant relationship with video gaming addiction. However, the literature suggests that video games are designed to have an interactive interface to engage consumers. In this regard, a mediating mechanism of absorption, immersion, and pleasure could be empirically tested to show how the interactive interfaces convert the video gaming engagement into video game addiction.

\section{Authors' Contributions}

UR and AZA worked on the idea development and conceptual design. ZA and MAR worked on the literature review, which was further edited by UR, AZA, and HH. AZA worked on the data analyses. MM and MUS improved the contents of the manuscript. All authors contributed to this paper and approved the submitted version.

\section{Conflicts of Interest}

None declared. 


\section{Multimedia Appendix 1}

Questionnaire used in this study.

[DOCX File, 25 KB-Multimedia Appendix 1]

\section{Multimedia Appendix 2}

Data analysis file.

[XLSX File (Microsoft Excel File), 43 KB-Multimedia Appendix 2]

\section{References}

1. Abbasi AZ, Shah MU, Rehman U, Hlavacs H, Ting DH, Nisar S. The Role of Personality Factors Influencing Consumer Video Game Engagement in Young Adults: A Study on Generic Games. IEEE Access 2021;9:17392-17410. [doi: 10.1109/access.2021.3053207]

2. Goethe O. Visual aesthetics in games and gamification. In: Gamification Mindset. Cham: Springer; 2019:85-92.

3. Santasärkkä S. The digital games industry and its direct and indirect impact on the economy. case study: supercell and Finland. Theseus. 2017. URL: https://www.theseus.fi/handle/10024/128453 [accessed 2021-11-15]

4. Zhu S, Zhuang Y, Lee P, Li JC, Wong PWC. Leisure and Problem Gaming Behaviors Among Children and Adolescents During School Closures Caused by COVID-19 in Hong Kong: Quantitative Cross-sectional Survey Study. JMIR Serious Games 2021 May 07;9(2):e26808 [FREE Full text] [doi: 10.2196/26808] [Medline: 33960954]

5. Mamun MA, Griffiths MD. The Psychosocial Impact of Extreme Gaming on Indian PUBG Gamers: the Case of PUBG (PlayerUnknown's Battlegrounds). Int J Ment Health Addiction 2019 May 22:1-5. [doi: 10.1007/s11469-019-00102-4]

6. Asghar M, Noor M. Relationship Between Temperament and Video Game Addiction among Youth. pjpbs 2017 Jan 05;2(2):285-298. [doi: 10.32879/pjpbs.2016.2.2.285-298]

7. Wang J, Rost DH, Qiao R, Monk R. Academic stress and smartphone dependence among Chinese adolescents: A moderated mediation model. Children and Youth Services Review 2020 Nov;118:105029. [doi: 10.1016/j.childyouth.2020.105029]

8. Anand V. A study of time management: the correlation between video game usage and academic performance markers. Cyberpsychol Behav 2007 Aug;10(4):552-559. [doi: 10.1089/cpb.2007.9991] [Medline: 17711364]

9. Bai C, Chen X, Han K. Mobile phone addiction and school performance among Chinese adolescents from low-income families: A moderated mediation model. Children and Youth Services Review 2020 Nov;118:105406. [doi: 10.1016/j.childyouth.2020.105406]

10. Wang L, Zhu S. Online game addiction among university students. University of Gavle. 2013. URL: https://www. diva-portal.org/smash/get/diva2:602320/FULLTEXT01.pdf [accessed 2021-11-15]

11. Liu Q, Yang X, Hu Y, Zhang C, Nie Y. How and when is family dysfunction associated with adolescent mobile phone addiction? Testing a moderated mediation model. Children and Youth Services Review 2020 Apr;111:104827. [doi: 10.1016/j.childyouth.2020.104827]

12. Lam LT. Internet gaming addiction, problematic use of the internet, and sleep problems: a systematic review. Curr Psychiatry Rep 2014 Apr;16(4):444. [doi: 10.1007/s11920-014-0444-1] [Medline: 24619594]

13. Chandrima RM, Kircaburun K, Kabir H, Riaz BK, Kuss DJ, Griffiths MD, et al. Adolescent problematic internet use and parental mediation: A Bangladeshi structured interview study. Addict Behav Rep 2020 Dec;12:100288 [FREE Full text] [doi: 10.1016/j.abrep.2020.100288] [Medline: 32637564]

14. Wong RSM, Ho FKW, Tung KTS, Fu K, Ip P. Effect of Pokémon Go on Self-Harm Using Population-Based Interrupted Time-Series Analysis: Quasi-Experimental Study. JMIR Serious Games 2020 Jun 12;8(2):e17112 [FREE Full text] [doi: 10.2196/17112] [Medline: 32530429]

15. Brunborg GS, Mentzoni RA, Melkevik OR, Torsheim T, Samdal O, Hetland J, et al. Gaming Addiction, Gaming Engagement, and Psychological Health Complaints Among Norwegian Adolescents. Media Psychology 2013 Jan;16(1):115-128. [doi: $10.1080 / 15213269.2012 .756374]$

16. Wang C, Chan C, Mak K, Ho S, Wong P, Ho R. Prevalence and correlates of video and internet gaming addiction among Hong Kong adolescents: a pilot study. ScientificWorldJournal 2014;2014:874648 [FREE Full text] [doi: 10.1155/2014/874648] [Medline: 25032242]

17. Hull DC, Williams GA, Griffiths MD. Video game characteristics, happiness and flow as predictors of addiction among video game players: A pilot study. Journal of Behavioral Addictions 2013 Sep;2(3):145-152. [doi: 10.1556/jba.2.2013.005]

18. Groves SJ, Skues JL, Wise LZ. Examining the Role of Personality Factors in Problematic Video Game Play Associated with Facebook Games. SN 2015;04(03):80-95. [doi: 10.4236/sn.2015.43010]

19. Blinka L, Škařupová K, Mitterova K. Dysfunctional impulsivity in online gaming addiction and engagement. Cyberpsychology 2016 Oct 01;10(3):1-9. [doi: 10.5817/cp2016-3-5]

20. Charlton JP, Danforth ID. Validating the distinction between computer addiction and engagement: online game playing and personality. Behaviour \& Information Technology 2010 Nov;29(6):601-613. [doi: 10.1080/01449290903401978] 
21. Loton D, Borkoles E, Lubman D, Polman R. Video Game Addiction, Engagement and Symptoms of Stress, Depression and Anxiety: The Mediating Role of Coping. Int J Ment Health Addiction 2015 Jul 31;14(4):565-578. [doi: 10.1007/s11469-015-9578-6]

22. Abbasi A, Ting D, Hlavacs H. Engagement in Games: Developing an Instrument to Measure Consumer Videogame Engagement and Its Validation. International Journal of Computer Games Technology 2017;2017:1-10. [doi: 10.1155/2017/7363925]

23. Gabriel Chong YM, Scott Teng KZ, Amy Siew SC, Skoric MM. Cultivation Effects of Video Games: A Longer-Term Experimental Test of First- and Second-Order Effects. Journal of Social and Clinical Psychology 2012 Nov;31(9):952-971. [doi: 10.1521/jscp.2012.31.9.952]

24. Skoric MM, Teo LLC, Neo RL. Children and video games: addiction, engagement, and scholastic achievement. Cyberpsychol Behav 2009 Oct;12(5):567-572. [doi: 10.1089/cpb.2009.0079] [Medline: 19624263]

25. Krossbakken E, Pallesen S, Mentzoni RA, King DL, Molde H, Finserås TR, et al. A Cross-Lagged Study of Developmental Trajectories of Video Game Engagement, Addiction, and Mental Health. Front Psychol 2018;9:2239 [FREE Full text] [doi: 10.3389/fpsyg.2018.02239] [Medline: 30519203]

26. Brunborg GS, Mentzoni RA, Frøyland LR. Is video gaming, or video game addiction, associated with depression, academic achievement, heavy episodic drinking, or conduct problems? Journal of Behavioral Addictions 2014 Mar;3(1):27-32. [doi: 10.1556/jba.3.2014.002]

27. Seok S, DaCosta B. The world's most intense online gaming culture: Addiction and high-engagement prevalence rates among South Korean adolescents and young adults. Computers in Human Behavior 2012 Nov;28(6):2143-2151. [doi: 10.1016/j.chb.2012.06.019]

28. Abbasi A, Ting D, Hlavacs H, Costa L, Veloso A. An empirical validation of consumer video game engagement: A playful-consumption experience approach. Entertainment Computing 2019 Mar;29:43-55 [FREE Full text] [doi: 10.1016/j.entcom.2018.12.002]

29. Abbasi AZ, Nisar S, Rehman U, Ting DH. Impact of HEXACO Personality Factors on Consumer Video Game Engagement: A Study on eSports. Front Psychol 2020;11:1831 [FREE Full text] [doi: 10.3389/fpsyg. 2020.01831] [Medline: 32849078]

30. Kaur P, Dhir A, Chen S, Malibari A, Almotairi M. Telematics and Informatics 2020 Oct;53:101376. [doi: 10.1016/j.tele.2020.101376]

31. Pham TTL, Huang H, Cheng T, Wong M, Liao Y, Yang Y, et al. The need for exercise in exergaming perspective of the uses and gratifications theory. IMDS 2020 May 23;120(6):1085-1099. [doi: 10.1108/imds-07-2019-0377]

32. van Rooij AJ, Van Looy J, Billieux J. Internet Gaming Disorder as a formative construct: Implications for conceptualization and measurement. Psychiatry Clin Neurosci 2017 Jul;71(7):445-458 [FREE Full text] [doi: 10.1111/pcn.12404] [Medline: 27193187]

33. Katz E, Blumler J, Gurevitch M. The Uses of Mass Communications: Current Perspectives on Gratifications Research. Oaks, CA: Sage Publications; 1974:0803903405.

34. Gerbner G. Cultivation Analysis: An Overview. Mass Communication and Society 1998 Jun;1(3-4):175-194. [doi: 10.1080/15205436.1998.9677855]

35. Wu J, Wang S, Tsai H. Falling in love with online games: The uses and gratifications perspective. Computers in Human Behavior 2010 Nov;26(6):1862-1871. [doi: 10.1016/j.chb.2010.07.033]

36. Rubin A. Uses and gratifications. In: The SAGE Handbook of Media Processes and Effects. Oaks, CA: Sage Publication; 2009:147-159.

37. Ruggiero TE. Uses and Gratifications Theory in the 21st Century. Mass Communication and Society 2000 Feb;3(1):3-37. [doi: $10.1207 / \mathrm{s} 15327825 \mathrm{mcs} 030102]$

38. Funk J, Buchman D. Playing violent video and computer games and adolescent self-concept. Journal of communication 1996;46(2):19-32. [doi: 10.1111/j.1460-2466.1996.tb01472.x]

39. Sherry J, Lucas K, Greenberg B, Lachlan K. Video game uses and gratifications as predictors of use and game preference. Playing video games: Motives, responses, and consequences 2006;24(1):213-224. [doi: 10.4324/9780203873700]

40. Sampat B, Krishnamoorthy B. Journal of International Technology and Information Management. 2016. URL: https:/ /scholarworks.lib.csusb.edu/jitim/vol25/iss3/5/ [accessed 2021-11-15]

41. Bouvier P, Lavoué E, Sehaba K. Defining Engagement and Characterizing Engaged-Behaviors in Digital Gaming. Simulation \& Gaming 2014 Nov 06;45(4-5):491-507. [doi: 10.1177/1046878114553571]

42. Bosser A, Nakatsu R. Hardcore gamers and casual gamers playing online together. In: Entertainment Computing. Berlin, Heidelberg: Springer; 2006:374-377.

43. Poels Y, Annema JH, Verstraete M, Zaman B, De Grooff D. Are you a gamer? a qualitative study on the parameters for categorizing casual and hardcore gamers. IJWI 2012:1-16. [doi: 10.33965/ijwi]

44. Hsu C, Lu H. Consumer behavior in online game communities: A motivational factor perspective. Computers in Human Behavior 2007 May;23(3):1642-1659. [doi: 10.1016/j.chb.2005.09.001]

45. Van Rooij AJ, Schoenmakers T, Vermulst A, Van den Eijnden RJJM, Van de Mheen D. Online video game addiction: identification of addicted adolescent gamers. Addiction 2011 Jan;106(1):205-212. [doi: 10.1111/j.1360-0443.2010.03104.X] [Medline: 20840209] 
46. Palmgreen P, Wenner L, Rosengren K. Uses and gratifications research: The past ten years. Media gratifications research: Current perspectives 1985;11:37.

47. Gerbner G. An institutional approach to mass communications research. Communication Theory and Research. 1967. URL: https://web.asc.upenn.edu/gerbner/Asset.aspx?assetID=302 [accessed 2021-11-15]

48. Borah P. Media Effects Theory. The international encyclopedia of political communication 2016:1-12. [doi: 10.1002/9781118541555.wbiepc156]

49. Riddle K. Cultivation theory revisited: the impact of childhood television viewing levels on social reality beliefs and construct accessibility in adulthood (conference papers). International Communication Association. 2009. URL: https:/ /tinyurl.com/6ra66fns [accessed 2021-11-15]

50. Cialdini R, Trost M. Social influence: social norms, conformity and compliance. In: The Handbook of Social Psychology. Boston: McGraw-Hill; 1998:151-192.

51. Fazio R, Roskos-Ewoldsen D, Powell M. Attitudes, perception, and attention. In: The Heart's Eye: Emotional Influences in Perception and Attention. San Diego: Academic Press; 1994:197-216.

52. Gerbner G, Gross L. Living with television: The violence profile. Journal of Communication 1976;26(2):172-199. [doi: 10.1111/j.1460-2466.1976.tb01397.x]

53. Valkenburg PM, Peter J, Walther JB. Media Effects: Theory and Research. Annu Rev Psychol 2016;67:315-338. [doi: 10.1146/annurev-psych-122414-033608] [Medline: 26331344]

54. Van Mierlo J, Van den Bulck J. Benchmarking the cultivation approach to video game effects: a comparison of the correlates of TV viewing and game play. J Adolesc 2004 Feb;27(1):97-111. [doi: 10.1016/j.adolescence.2003.10.008] [Medline: 15013263]

55. Jin SA. "It Feels Right. Therefore, I Feel Present and Enjoy": The Effects of Regulatory Fit and the Mediating Roles of Social Presence and Self-Presence in Avatar-Based 3D Virtual Environments. Presence: Teleoperators and Virtual Environments 2011 Apr 01;20(2):105-116. [doi: 10.1162/pres a 00038]

56. Shang C, Williams T, Beavis A, Ward J, Sims C, Phillips R. SU-FF-T-117: Can Current Prostate IMRT Be Further Improved with Immersive Virtual Reality Simulation? Med. Phys 2006 Jul 11;33(6Part8):2075-2076. [doi: 10.1118/1.2241042]

57. Seah M, Cairns P. From immersion to addiction in videogames. 2008 Presented at: 22nd British HCI Group Annual Conference on People and Computers: Culture, Creativity, Interaction; September 1-5, 2008; Liverpool, UK p. 55-63. [doi: 10.14236/ewic/hci2008.6]

58. Quwaider M, Alabed A, Duwairi R. The Impact of Video Games on the Players Behaviors: A Survey. Procedia Computer Science 2019;151:575-582. [doi: 10.1016/j.procs.2019.04.077]

59. Prot S, Gentile DA, Anderson CA, Suzuki K, Swing E, Lim KM, et al. Long-term relations among prosocial-media use, empathy, and prosocial behavior. Psychol Sci 2014 Feb;25(2):358-368. [doi: 10.1177/0956797613503854] [Medline: 24335350]

60. Fuster H, Chamarro A, Carbonell X, Vallerand RJ. Relationship between passion and motivation for gaming in players of massively multiplayer online role-playing games. Cyberpsychol Behav Soc Netw 2014 May;17(5):292-297. [doi: 10.1089/cyber.2013.0349] [Medline: 24611801]

61. Wittek CT, Finserås TR, Pallesen S, Mentzoni RA, Hanss D, Griffiths MD, et al. Prevalence and Predictors of Video Game Addiction: A Study Based on a National Representative Sample of Gamers. Int J Ment Health Addict 2016;14(5):672-686 [FREE Full text] [doi: 10.1007/s11469-015-9592-8] [Medline: 27688739]

62. Porter JR. Understanding and addressing real-world accessibility issues in mainstream video games. SIGACCESS Access. Comput 2014 Jan(108):42-45. [doi: 10.1145/2591357.2591364]

63. van Rooij AJ, Kuss DJ, Griffiths MD, Shorter GW, Schoenmakers TM, van de Mheen D. The (co-)occurrence of problematic video gaming, substance use, and psychosocial problems in adolescents. Journal of Behavioral Addictions 2014 Sep;3(3):157-165. [doi: 10.1556/jba.3.2014.013]

64. Asghar M, Noor M. Relationship Between Temperament and Video Game Addiction among Youth. pjpbs 2017 Jan 05;2(2):285-298. [doi: 10.32879/pjpbs.2016.2.2.285-298]

65. Banyte J, Gadeikiene A. The Effect of Consumer Motivation to Play Games on Video Game-playing Engagement. Procedia Economics and Finance 2015;26:505-514 [FREE Full text] [doi: 10.1016/s2212-5671(15)00880-1]

66. Brown E, Cairns P. A grounded investigation of game immersion. 2004 Presented at: CHI EA '04; April; Vienna, Austria. [doi: $\underline{10.1145 / 985921.986048]}$

67. Rigby S, Ryan R. Glued to Games: How Video Games Draw Us In and Hold Us Spellbound. USA: Praeger; Illustrated edition; Feb 18, 2011.

68. Przybylski AK, Rigby CS, Ryan RM. A Motivational Model of Video Game Engagement. Review of General Psychology 2010 Jun 01;14(2):154-166. [doi: 10.1037/a0019440]

69. Renninger K, Hidi S, Krapp A, Renninger A. The Role of Interest in Learning and Development. New York: Taylor \& Francis; 2014.

70. Adams E, Rollings A. Fundamentals of Game Design. Berkeley, CA: Pearson Prentice Hall; 2007.

71. Jennett C, Cox AL, Cairns P, Dhoparee S, Epps A, Tijs T, et al. Measuring and defining the experience of immersion in games. International Journal of Human-Computer Studies 2008 Sep;66(9):641-661. [doi: 10.1016/j.ijhcs.2008.04.004] 
72. Lombard M, Ditton T. At the heart of it all: The concept of presence. Journal of computer-mediated communication 1997;3(2). [doi: 10.1111/j.1083-6101.1997.tb00072.x]

73. Chen J. Flow in games (and everything else). Commun. ACM 2007 Apr;50(4):31-34. [doi: 10.1145/1232743.1232769]

74. Koster R. Theory of Fun for Game Designers. Scottsdale, Arizona: Paraglyph Press; 2005.

75. IJsselsteijn W, Van DHW, Klimmt C, De KY, Lindley C, Mathiak K. Measuring the experience of digital game enjoyment. Psychology of Digital Games. 2008. URL: https://www.researchgate.net/publication/

254415787_Measuring_the_experience_of_digital_game_enjoyment [accessed 2021-11-15]

76. Calleja G. In-game: From Immersion to Incorporation. Harvard: MIT Press; 2011.

77. Hollebeek LD, Glynn MS, Brodie RJ. Consumer Brand Engagement in Social Media: Conceptualization, Scale Development and Validation. Journal of Interactive Marketing 2014 May;28(2):149-165. [doi: 10.1016/j.intmar.2013.12.002]

78. Kuvykaitė R, Tarutė A. A Critical Analysis of Consumer Engagement Dimensionality. Procedia - Social and Behavioral Sciences 2015 Dec;213:654-658. [doi: 10.1016/j.sbspro.2015.11.468]

79. Brodie RJ, Ilic A, Juric B, Hollebeek L. Consumer engagement in a virtual brand community: An exploratory analysis. Journal of Business Research 2013 Jan;66(1):105-114. [doi: 10.1016/j.jbusres.2011.07.029]

80. Charlton JP, Danforth ID. Distinguishing addiction and high engagement in the context of online game playing. Computers in Human Behavior 2007 May;23(3):1531-1548. [doi: 10.1016/j.chb.2005.07.002]

81. Griffiths MD. Videogame Addiction: Further Thoughts and Observations. Int J Ment Health Addiction 2007 Sep 18;6(2):182-185. [doi: 10.1007/s11469-007-9128-y]

82. Seok S, DaCosta B. Distinguishing Addiction From High Engagement. Games and Culture 2014 Jul 13;9(4):227-254. [doi: $10.1177 / 1555412014538811]$

83. Mentzoni RA, Brunborg GS, Molde H, Myrseth H, Skouverøe KJM, Hetland J, et al. Problematic video game use: estimated prevalence and associations with mental and physical health. Cyberpsychol Behav Soc Netw 2011 Oct;14(10):591-596. [doi: 10.1089/cyber.2010.0260] [Medline: 21342010]

84. Eklund L. Playing video games together with others: Differences in gaming with family, friends and strangers. journal of gaming \& virtual worlds 2015 Sep 01;7(3):259-277. [doi: 10.1386/jgvw.7.3.259_1]

85. Kallio KP, Mäyrä F, Kaipainen K. At Least Nine Ways to Play: Approaching Gamer Mentalities. Games and Culture 2010 Dec 31;6(4):327-353. [doi: 10.1177/1555412010391089]

86. Van den Bulck H, Van Aelst P. Het Etmaal van de Communicatiewetenschap: Een lokale anomalie in een globaliserend academisch veld? Tijdschrift voor Communicatiewetenschappen 2007 Dec;35(4):269-274. [doi: 10.1347/tijd.35.4.269]

87. Schuurman D, De MK, De ML, Van LJ, editors. Fanboys, competers, escapists and time-killers: a typology based on gamers' motivations for playing video games. 2008 Presented at: 3rd International Conference on Digital Interactive Media in Entertainment and Arts; September 10-12, 2008; Athens, Greece. [doi: 10.1145/1413634.1413647]

88. Juul J. A Casual Revolution: Reinventing Video Games and Their Players. Cambridge, MA: MIT press; 2010.

89. Kuittinen J, Kultima A, Niemel J, Paavilainen J. Casual games discussion. 2007 Presented at: Proceedings of the 2007 conference on Future Play; November; Toronto, Canada p. 166-173. [doi: 10.1145/1328202.1328221]

90. Conrad D. The compatibility of artworks and games. Trinity University. 2016. URL: https://digitalcommons.trinity.edu/ cgi/viewcontent.cgi?article=1031\&context=infolit_usra [accessed 2020-11-12]

91. Griffiths M. A 'components' model of addiction within a biopsychosocial framework. Journal of Substance Use 2009 Jul 12;10(4):191-197. [doi: 10.1080/14659890500114359]

92. van RA, Schoenmakers T, Vermulst A, van DER, van DMD. Online video game addiction: identification of addicted adolescent gamers. Addiction 2010;8:11. [doi: 10.1111/j.1360-0443.2010.03104.x]

93. Vivek SD, Beatty SE, Morgan RM. Customer Engagement: Exploring Customer Relationships Beyond Purchase. Journal of Marketing Theory and Practice 2014 Dec 08;20(2):122-146. [doi: 10.2753/mtp1069-6679200201]

94. Csikszentmihalyi M. Flow. In: The Psychology of Optimal Experience. New York: Cambridge University Press; 1990.

95. Bowman N, Kowert R, Ferguson C. The impact of video game play on human (and orc) creativity. In: Video Games and Creativity. Amsterdam: Academic Press, Elsvier; 2015.

96. De Pasquale C, Dinaro C, Sciacca F. Relationship of Internet gaming disorder with dissociative experience in Italian university students. Ann Gen Psychiatry 2018;17:28 [FREE Full text] [doi: 10.1186/s12991-018-0198-y] [Medline: 29983724]

97. Chou T, Ting C. The role of flow experience in cyber-game addiction. Cyberpsychol Behav 2003 Dec;6(6):663-675. [doi: 10.1089/109493103322725469] [Medline: 14756934]

98. Hollebeek LD. Demystifying customer brand engagement: Exploring the loyalty nexus. Journal of Marketing Management 2011 Jul;27(7-8):785-807. [doi: 10.1080/0267257x.2010.500132]

99. Mollen A, Wilson H. Engagement, telepresence and interactivity in online consumer experience: Reconciling scholastic and managerial perspectives. Journal of Business Research 2010 Sep;63(9-10):919-925. [doi: 10.1016/j.jbusres.2009.05.014]

100. Hollebeek L. Exploring customer brand engagement: definition and themes. Journal of Strategic Marketing 2011 Dec;19(7):555-573. [doi: 10.1080/0965254x.2011.599493]

101. Nakamura J, Csikszentmihalyi M. The concept of flow. In: Flow and the Foundations of Positive Psychology. Cham: Springer; 2014:239-263. 
102. DeCharms R. Personal Causation: The Internal Affective Determinants of Behavior. New York: Academic Press; 1968.

103. Haladjian H, Montemayor C. Unifying theories of consciousness, attention, and conscious attention. 2013 Presented at: Annual Meeting of the Cognitive Science Society; July 31-August 3, 2013; Berlin, Germany. [doi: 10.7551/mitpress/9780262028974.003.0004]

104. Vivek SD, Beatty SE, Dalela V, Morgan RM. A Generalized Multidimensional Scale for Measuring Customer Engagement. Journal of Marketing Theory and Practice 2014 Dec 07;22(4):401-420. [doi: 10.2753/mtp1069-6679220404]

105. Jansz J, Martens L. Gaming at a LAN event: the social context of playing video games. New Media \& Society 2016 Jun 30;7(3):333-355. [doi: 10.1177/1461444805052280]

106. Krotoski A. Chicks and joysticks: an exploration of women and gaming. Psychology. 2004. URL: https://tinyurl.com/ 3j37bpjh [accessed 2021-11-15]

107. Weibel D, Wissmath B, Habegger S, Steiner Y, Groner R. Playing online games against computer- vs. human-controlled opponents: Effects on presence, flow, and enjoyment. Computers in Human Behavior 2008 Sep;24(5):2274-2291. [doi: 10.1016/j.chb.2007.11.002]

108. Valkenburg P, Peter J. Online communication and adolescent well-being: Testing the stimulation versus the displacement hypothesis. Journal of Computer-Mediated Communication 2007;12(4):1169-1182. [doi: 10.1111/j.1083-6101.2007.00368.x]

109. Sioni SR, Burleson MH, Bekerian DA. Internet gaming disorder: Social phobia and identifying with your virtual self. Computers in Human Behavior 2017 Jun;71:11-15. [doi: 10.1016/j.chb.2017.01.044]

110. Cole H, Griffiths MD. Social interactions in massively multiplayer online role-playing gamers. Cyberpsychol Behav 2007 Aug;10(4):575-583. [doi: 10.1089/cpb.2007.9988] [Medline: 17711367]

111. Peters CS, Malesky LA. Problematic usage among highly-engaged players of massively multiplayer online role playing games. Cyberpsychol Behav 2008 Aug;11(4):481-484. [doi: 10.1089/cpb.2007.0140] [Medline: 18721098]

112. So KKF, King C, Sparks B. Customer Engagement With Tourism Brands. Journal of Hospitality \& Tourism Research 2012 Jul 03;38(3):304-329. [doi: 10.1177/1096348012451456]

113. Morrison M, Krugman DM. A Look At Mass and Computer Mediated Technologies: Understanding the Roles of Television and Computers in the Home. Journal of Broadcasting \& Electronic Media 2001 Mar;45(1):135-161. [doi: $10.1207 / \mathrm{s} 15506878$ jobem4501 9]

114. Sedig K, Parsons P. Interaction Design for Complex Cognitive Activities with Visual Representations: A Pattern-Based Approach. THCI 2013 Jun 30;5(2):84-133. [doi: 10.17705/1thci.00055]

115. Granic I, Lobel A, Engels RCME. The benefits of playing video games. Am Psychol 2014 Jan;69(1):66-78. [doi: 10.1037/a0034857] [Medline: 24295515]

116. Krueger AB. How Computers Have Changed the Wage Structure: Evidence from Microdata, 1984-1989. The Quarterly Journal of Economics 1993 Feb 01;108(1):33-60. [doi: 10.2307/2118494]

117. Wan RW, Hamid X, Sabri M. Video games: issues and problems. : IEEE xplore; 2007 Presented at: 5th International Conference on Information and Communications Technology; Dec 16-18, 2007; Cairo, Egypt. [doi: 10.1109/itict.2007.4475651]

118. Griffiths M, Hussain Z, Grüsser S, Thalemann R, Cole H, Davies M. Social interactions in online gaming. International Journal of Game-Based Learning 2011;1(4):20-36. [doi: 10.4018/ijgbl.2011100103]

119. Sedgwick P. Cross sectional studies: advantages and disadvantages. BMJ 2014 Mar 26;348:g2276-g2276. [doi: 10.1136/bmj.g2276]

120. Abbasi A, Ting D, Hlavacs H. A New Scale Development. : Springer, Cham; 2016 Presented at: International Conference on Entertainment Computing; September 2016; Austria p. 247-252. [doi: 10.1007/978-3-319-46100-7 25]

121. Lemmens JS, Valkenburg PM, Peter J. Development and Validation of a Game Addiction Scale for Adolescents. Media Psychology 2009 Mar 05;12(1):77-95. [doi: 10.1080/15213260802669458]

122. Hair JJ, Hult G, Ringle C, Sarstedt M. An introduction to structural equation modeling. In: Partial Least Squares Structural Equation Modeling (PLS-SEM) Using R. Cham: Springer; 2021.

123. Emmel N. Purposeful sampling. Sampling and choosing cases in qualitative research: A realist approach 2013:33-45. [doi: 10.4135/9781473913882.n3]

124. Abbasi AZ, Asif M, Hollebeek LD, Islam JU, Ting DH, Rehman U. The effects of consumer esports videogame engagement on consumption behaviors. Journal of Product \& Brand Management. 2020 Dec 07. URL: https://www.researchgate.net/ publication/345061354 The effect of consumer esports videogame engagement on consumption behaviors [accessed 2021-11-15]

125. Abbasi A, Shamim A, Hooi TD, Hlavacs H, Rehman U. Playful-consumption experiences and subjective well-being: Children?s smartphone usage. Entertainment Computing 2021:100390 [FREE Full text] [doi: 10.1016/j.entcom.2020.100390]

126. Hair J, Hollingsworth CL, Randolph AB, Chong AYL. An updated and expanded assessment of PLS-SEM in information systems research. IMDS 2017 Apr 10;117(3):442-458. [doi: 10.1108/imds-04-2016-0130]

127. Chang C, Yeh S, Li M. The Adoption of a Virtual Reality-Assisted Training System for Mental Rotation: A Partial Least Squares Structural Equation Modeling Approach. JMIR Serious Games 2020 Jan 17;8(1):e14548 [FREE Full text] [doi: 10.2196/14548] [Medline: 31804184] 
128. Hair JF, Risher JJ, Sarstedt M, Ringle CM. When to use and how to report the results of PLS-SEM. EBR 2019 Jan 14;31(1):2-24. [doi: 10.1108/ebr-11-2018-0203]

129. Kock N. WarpPLS user manual: Version 6. ScriptWarp Systems. 2017. URL: http://cits.tamiu.edu/WarpPLS/ UserManual_v_6_0.pdf [accessed 2021-11-15]

130. Henseler J, Ringle CM, Sarstedt M. A new criterion for assessing discriminant validity in variance-based structural equation modeling. J. of the Acad. Mark. Sci 2014 Aug 22;43(1):115-135. [doi: 10.1007/s11747-014-0403-8]

131. Becker J, Klein K, Wetzels M. Hierarchical Latent Variable Models in PLS-SEM: Guidelines for Using Reflective-Formative Type Models. Long Range Planning 2012 Oct;45(5-6):359-394. [doi: 10.1016/j.lrp.2012.10.001]

132. Sarstedt M, Hair JF, Cheah J, Becker J, Ringle CM. How to Specify, Estimate, and Validate Higher-Order Constructs in PLS-SEM. Australasian Marketing Journal 2021 Jan 27;27(3):197-211. [doi: 10.1016/j.ausmj.2019.05.003]

133. Bhagat S, Jeong EJ, Kim DJ. The Role of Individuals' Need for Online Social Interactions and Interpersonal Incompetence in Digital Game Addiction. International Journal of Human-Computer Interaction 2019 Aug 29;36(5):449-463. [doi: 10.1080/10447318.2019.1654696]

134. von der Heiden JM, Braun B, Müller KW, Egloff B. The Association Between Video Gaming and Psychological Functioning. Front Psychol 2019;10:1731 [FREE Full text] [doi: 10.3389/fpsyg.2019.01731] [Medline: $\underline{31402891]}$

135. Wood RTA. Problems with the Concept of Video Game "Addiction": Some Case Study Examples. Int J Ment Health Addiction 2007 Oct 23;6(2):169-178. [doi: 10.1007/s11469-007-9118-0]

136. Funk D, Mahony D, Ridinger L. Characterizing consumer motivation as individual difference factors: Augmenting the sports interest inventory (SII) to explain level of spectator support. Sport Marketing Quarterly 2002;11(1):A.

137. Corcoran R. Combined group proposal for individuals experiencing online video game addiction. California State University. 2016. URL: https://scholarworks.csun.edu/bitstream/handle/10211.3/183082/Corcoran-Rory-thesis-2017.pdf?sequence=1 [accessed 2020-10-11]

138. Barnes SJ, Pressey AD, Scornavacca E. Mobile ubiquity: Understanding the relationship between cognitive absorption, smartphone addiction and social network services. Computers in Human Behavior 2019 Jan;90:246-258. [doi: 10.1016/j.chb.2018.09.013]

139. Seay A, Kraut R. Project massive: Self-regulation and problematic use of online gaming. 2007 Presented at: SIGCHI conference on human factors in computing systems; April 28-May 3, 2007; San Jose, California, USA. [doi: 10.1145/1240624.1240749]

140. Van RA. Online video game addiction: exploring a new phenomenon. Erasmus MC: University Medical Center Rotterdam. 2011. URL: https://repub.eur.nl/pub/23381/ [accessed 2021-01-02]

141. Schmitt ZL, Livingston MG. Video game addiction and college performance among males: results from a 1 year longitudinal study. Cyberpsychol Behav Soc Netw 2015 Jan;18(1):25-29. [doi: 10.1089/cyber.2014.0403] [Medline: 25584728]

142. Bhagat S, Jeong EJ, Kim DJ. The Role of Individuals' Need for Online Social Interactions and Interpersonal Incompetence in Digital Game Addiction. International Journal of Human-Computer Interaction 2019 Aug 29;36(5):449-463. [doi: 10.1080/10447318.2019.1654696]

143. Yayan EH, Suna Dağ Y, Düken ME. The effects of technology use on working young loneliness and social relationships. Perspect Psychiatr Care 2019 Apr;55(2):194-200. [doi: 10.1111/ppc.12318] [Medline: 30044497]

144. Kim J, LaRose R, Peng W. Loneliness as the cause and the effect of problematic Internet use: the relationship between Internet use and psychological well-being. Cyberpsychol Behav 2009 Aug;12(4):451-455. [doi: 10.1089/cpb.2008.0327] [Medline: 19514821$]$

145. Stein J, Krause E, Ohler P. Every (Insta)Gram counts? Applying cultivation theory to explore the effects of Instagram on young users' body image. Psychology of Popular Media 2021 Jan;10(1):87-97. [doi: 10.1037/ppm0000268]

146. LaGrotta C. Gender Differences in Addiction. Curr Addict Rep 2021 Jan 18;8(1):64-70. [doi: 10.1007/s40429-021-00355-x]

\section{Abbreviations}

MMORPG: massively multiplayer online role-playing game

PLS-SEM: partial least squares-structural equation modeling

UGT: uses and gratifications theory 
Edited by N Zary; submitted 10.05.21; peer-reviewed by D Parry, O Blanson Henkemans; comments to author 03.08.21; revised version received 28.09.21; accepted 12.10.21; published 26.11.21

Please cite as:

Abbasi AZ, Rehman U, Afaq Z, Rafeh MA, Hlavacs H, Mamun MA, Shah MU

Predicting Video Game Addiction Through the Dimensions of Consumer Video Game Engagement: Quantitative and Cross-sectional Study

JMIR Serious Games 2021;9(4):e30310

URL: https://games.jmir.org/2021/4/e30310

doi: $\underline{10.2196 / 30310}$

PMID:

(C)Amir Zaib Abbasi, Umair Rehman, Zahra Afaq, Mir Abdur Rafeh, Helmut Hlavacs, Mohammed A Mamun, Muhammad Umair Shah. Originally published in JMIR Serious Games (https://games.jmir.org), 26.11.2021. This is an open-access article distributed under the terms of the Creative Commons Attribution License (https://creativecommons.org/licenses/by/4.0/), which permits unrestricted use, distribution, and reproduction in any medium, provided the original work, first published in JMIR Serious Games, is properly cited. The complete bibliographic information, a link to the original publication on https://games.jmir.org, as well as this copyright and license information must be included. 